\title{
Drying Temperature Effect on Total Phenols and Flavonoids Content, and Antioxidant Activity of Borassus aethiopum Mart Ripe Fruits' Pulp
}

\author{
Tagouèlbè Tiho ${ }^{1}, \mathrm{~N}^{\prime}$ guessan J. C. Yao ${ }^{2}$, Yao C. Brou ${ }^{3} \&$ Amissa A. Adima ${ }^{2}$ \\ ${ }^{1}$ Laboratory of Animal Science, Department of Agriculture et Animal Resources, National Polytechnic Institute \\ Félix Houphouët Boigny (INP-HB), Yamoussoukro, Côte d'Ivoire \\ ${ }^{2}$ Laboratory of Industrial Processes, Synthesis, Environment and New Energies, National Polytechnic Institute \\ Félix Houphouët Boigny (INP-HB), Yamoussoukro, Côte d'Ivoire \\ ${ }^{3}$ Laboratory of Agronomy, Department of Agriculture and Animal Resources, National Polytechnic Institute \\ Félix Houphouët Boigny (INP-HB), Yamoussoukro, Côte d'Ivoire \\ Correspondence: Tagouèlbè Tiho, Laboratory of Animal Science, Department of Agriculture and Animal \\ Resources, INP-HB, P.o.Box 1313 Yamoussoukro, Côte d'Ivoire. Tel: 225-0587-3114. Email: \\ tihotag@gmail.com
}

Received: January 14, 2017

Accepted: February 21, $2017 \quad$ Online Published: March 2, 2017

doi:10.5539/jfr.v6n2p50

URL: http://dx.doi.org/10.5539/jfr.v6n2p50

\begin{abstract}
We assessed the total phenols content (TPC) by Folin-Ciocalteux method, total flavonoids content (TFC), and antioxidant activity (AOA) using ABTS radical cation of Borassus aethiopum Mart ripe fruits; uniquely its pulp was considered. Fresh and dried at $40,50,60,70$ and $80^{\circ} \mathrm{C}$ pulps were analyzed, through maceration and decoction, and distilled water (DW), aqueous acetone (DW+Aceto, DW/acetone, 30/70, v/v) and aqueous methanol (DW+Meth) prepared in the same way were used. Though $80^{\circ} \mathrm{C}$ product extracted through decoction delivered the highest extracts of TPC with DW, DW+Aceto and DW+Meth, 654.434, 780.066 and $729.934 \mathrm{mg}$ $\mathrm{GAE} / \mathrm{g}$ respectively; we could not retain it as the best. Very likely, the sugars were caramelizing and the derived product had an intense brown color. Whereas, at $70^{\circ} \mathrm{C}$, TPCs were $447.866,337.334$ and $327.066 \mathrm{mg} \mathrm{GAE} / \mathrm{g}$, respectively, by decoction and in the same above solvents order. The best extract obtained with DW was statistically different from that of DW + Aceto and DW + Meth, which were not significantly different from each other, with Duncan least squares means comparison test in a confidence interval of $99 \%$. The corresponding TFCs and AOAs were $(59.34,68.34$, and $51.66 \mathrm{mg} \mathrm{QE} / \mathrm{g})$ and $(0.4404,0.52088$, and $0.6524 \mu \mathrm{mol} \mathrm{TE} / \mathrm{g})$. The flour has a nice chocolate color. Except $60^{\circ} \mathrm{C}$, an increase of the drying temperature leaded to a rising amount of TPC. Taking each factor, the extraction mode and drying temperature were main effects for extracts $(\mathrm{p}<0.0001)$. The overall regression analysis showed significant correlation coefficient between TPC and AOA, with $\mathrm{R}^{2}=0.8394$.
\end{abstract}

Keywords: ABTS, antioxidant activity, Borassus aethiopum Mart, flavonoids, Folin-Ciocalteux, phenols

\section{Introduction}

Among the agricultural products, the grains such as corn, rice, sorghum, millet and some leguminous whose group peas, beans and soya have a very low water content at physiological maturity. In contrary a lot of agricultural products are bulky with very high water content; among those are yams, cassava, potatoes, and a large variety of fruits. Subsequently, due to their high water content they are very perishable (Ali, Alhadji, Tchiegang, \& Saidou, 2010a). So in the aim to reduce this perishability and enhance their shelf life, in natural conditions considering ambient humidity and temperature, the drying methods are being used since antiquity. Indeed, according to Ali et al. (2010a) drying contributes to reduce weight and ease transport. Conversely, drying is a trade-off between the enhancement of the shelf life and the nutritional quality of the derived dried food. Many fruits are qualified to be very rich in various vitamins such as A, B, C, and others (Ali et al., 2010a). Most of these vitamins can't be synthetized by human being organism, whereas though they are crucially important for a good metabolism. Unfortunately, many of these micronutrients are denatured by heat. Regarding vitamin $\mathrm{C}$, at 50,60 and $70^{\circ} \mathrm{C}$ the phytochemical losses were 69.1, 80, and $86 \%$ respectively (Veras, Bettega, F. Freire, 
Barrozo, \& J. Freire, 2012). In the same way, Mkandawire, Manani, Mkabambe and Phiri (2016) realized that compare to $15^{\circ} \mathrm{C}$, storing processed mango juice at $30^{\circ} \mathrm{C}$ leaded to higher losses in vitamin $\mathrm{C}$.

Beside the phytochemical vitamin $\mathrm{C}$, phenolic compounds are known to have important health benefits. For instance, Karaca and Newman (2015) shown that natural phenolic compound from plants contain major antimicrobial components, thus contribute to control foodborne pathogens. In contrary to heat depressive effect on vitamin C, by changing the heating temperature and its duration, Jeong et al. (2004) demonstrated that antioxidant activities and total phenolic content of citrus peel can change increasingly following the temperature elevation in certain drying temperature and heat duration interval. As an illustration, compared to non-heat treated control, heat treatment of citrus peels at $150^{\circ} \mathrm{C}$ for one hour increased the total phenols content (TPC), and radical scavenging activity (RSA) of $70 \%$ ethanol extract from 71.8 to 171.0 micromole tannic acid equivalent per millilitre $(\mu \mathrm{mol} \mathrm{TAE} / \mathrm{ml})(138.18 \%)$, and from 29.64 to $64.25 \%$ (116.77\%) of inhibition, respectively.

So, we may think that higher temperature may lead to higher values of TPC and RSA. In contrast, working with Litchi fruit pericarp tissues at $25,35,45,55$ and $65^{\circ} \mathrm{C}$, Ruenroengklin et al. (2008) showed that the heating interval from 45 to $60^{\circ} \mathrm{C}$ exhibited a relatively high antioxidant activity. Importantly, when people are looking for polyphenols source by eating potatoes, Lachman, Hamouz, Sulc, Orsak and Dvoral (2008) proved that compare to yellow-fleshed, purple-fleshed potatoes should be preferred. In brief, this finding revealed the importance of raw material colour at maturity as polyphenols potential source. Interestingly, Dantas et al. (2016) confirmed that during the ripping period, total chlorophyll content declines when polyphenols compound content such as carotenoids increases, leading to an improvement of total antioxidant activity.

In fact, beside common agricultural products, the contribution of non-timber forest products (NTFP) to rural populations' wellbeing is getting more and more important (Dantas et al. 2016). In addition to the traditional medicine benefits, Borassus aethiopum fruits contribute greatly to poverty alleviation (Ali et al., 2010a; Ali, Fadimatou, Tchiegang, Saidou, \& Adji, 2010b; Ali, Tchiegang, Alhadji, Saidou, \& Mohamadou, 2010c). They mentioned that, in West Africa, all part of B. aethiopum Mart trees is used. Additionally, its fruits provide an abundant yellow-orange fibrous pulp that rural people cook for porridge. Furthermore, these fruits' kernels can be sowed in grumble sand, and then the germinating shoots are harvested 6 to 8 months later, dried to make edible flour, as illustrated by Barminas et al. (2008).

Due to the revealed importance of orange, purple or yellow coloured foodstuffs, known as important sources of polyphenols (Lachman et al., 2008; Dantas et al., 2016), whilst we didn't come across of a paper on the drying temperature impact on Palmira palm pulp nutritional value, we assessed B. aethiopum mature fruits pulp nutritional quality under different drying temperatures. So, the hypothesis investigated in this paper was that the drying temperature can affect total phenols and flavonoids content, thus the antioxidant activity of Borassus aethiopum Mart ripe fruits' pulp. This investigation aims to ascertain the best drying temperature that leads to the highest nutritional value in terms of total phenols and total flavonoids content, thus the best antioxidant activity. Alongside these direct assessments on TPC, TFC and AOA, an implicit question was "is product, solvent or extraction a main effect for the extracts?". This result may be useful to small and middle size companies which could promote the uses of B. aethiopum Mart dried pulp in human nutrition for its nutritional health benefits.

\section{Materials and Methods}

\subsection{Samples Preparation}

Firstly, daily fallen B. aethiopum Mart ripe fruits were collected in the garden of the graduate school of agriculture, at National Polytechnic Institute Felix Houphouet Boigny in Yamoussoukro (Côte d'Ivoire). They were sorted, undamaged by falling choc and unspoiled were kept for two or three days more in the laboratory at room temperature. During this short storage period, the yellowish hard skin softens a bit. Secondly, the sepals were taken off, and the fruits were washed with fresh water to eliminate all impurities. Then, using a sharpened knife, the fruits were peeled. The kernels were separated, and finally the fibrous pulp was removed. Thirdly, the obtained pulp was dried into oven at different temperatures $\left(40,50,60,70\right.$ and $\left.80^{\circ} \mathrm{C}\right)$ until reaching an unchanged weight evolution, meaning the pulp could not release any more water. The pulp was laid thinly on the perforated aluminium tray, then it needed 8,7,6,5 and 4 days for reaching the constant weight, respectively, from the lowest to the highest drying temperature. Using a traditional wooden mortar, the samples were crushed just after taking them out of oven. Therefore, they were powdered and with a laboratory test sieve (Iso 3310-1BODY 36 LMESHS-Steel / RF S/N 04003699, Body $=200 \mathrm{~mm} \times 50 \mathrm{~mm}$ ) the fine powder was separated from the big particles. The fine dried pulp was collected, placed in dark plastic bags in accordance with the drying temperature, and kept in dry places at room temperature, out of light until analysis. 


\subsection{Solvents Preparation and Extractions}

Before extraction, for dried products, about 2 grams of each sample were reheated at their previous drying temperature for one hour in order to remove the humidity. Thereafter, they were cooled in a silica gel bottle for 30 minutes for water vapours cleaning. Finally, one gram (fresh or dried) was used for one extraction. Three solvents, which were distilled water (DW), analytic Methanol solution (DW/Meth, 30/70, v/v) (DW+Meth), and analytic Acetone solution (DW+Aceto) formulated in the same way, were made following Jeong et al. (2004) approach. Also, when Karimi, Min, Brownmiller and Lee (2015) checked for the best solvent and water mixing ratio for total phenols and scavenging activity assessments, they came to the conclusion that $60 / 40$ and 80/20 delivered the highest extracts. Furthermore, these extracts were not significantly different. So, we decided to stay in the middle by using a mixing ratio of 70/30. Regarding the extraction methods, the decoction and the maceration were performed. Firstly, the maceration was performed by putting 1 gram of the sample in a $50 \mathrm{ml}$ flask container and poured $20 \mathrm{ml}$ of solvent. A magnetic agitator was immerged in the solution, and the flask was therefore put on an electric agitator. The container was closed to avoid evaporation, and the extraction lasted 8 hours. Using combed cotton, the solution was filtered. Secondly, for the decoction, a closed circuit system was made by adding a cooling system on a heating one. As the previous method, the same preparation was done, and the flask was heated at $100^{\circ} \mathrm{C}$ for 30 minutes on an electric furnace. Just after, the heater was turn off and removed under the flask. Then, the solution was kept on the cooling system for some additional 30 minutes to collect the last drops. To end, the decoction was filtrated.

\subsection{Spectrophotometric Determination of Total Phenols}

The method of Wood, Senthilmohan and Peskin (2002) was used for the determination of total phenols. A volume of $2.5 \mathrm{ml}$ of Folin-Ciocalteu reagent diluted to one-tenth was added to $30 \mu \mathrm{l}$ of the extract. The mixture was kept for 2 minutes in the dark at room temperature, then $2 \mathrm{ml}$ of sodium carbonate solution $(75 \mathrm{~g} / \mathrm{l})$ were added. Then the mixture was placed for 15 minutes in a water bath at $50^{\circ} \mathrm{C}$ and then quickly cooled. The absorbance was measured at $760 \mathrm{~nm}$, using a UV-visible spectrophotometer (Shimadzu UV-1601 PC, Kyoto, Japan), with distilled water as a blank. A calibration curve $\left(\mathrm{R}^{2}=0.9607\right)$ was performed with Gallic acid at different concentrations (Figure 1$)$. The assays were performed in triplicate and the total phenols content was expressed as gram Gallic acid equivalent per litre (g GAE/l) of extracts. In details, from $1 \mathrm{~g}$ of a given product (fresh or dried) in $20 \mathrm{ml}$ of solvent during the maceration or decoction, we had $1.5 \mathrm{mg}$ of the product in $4.53 \mathrm{ml}$ of Folin-Ciocalteux and sodium carbonate solution. The obtained results through the spectrophotometer can be converted into gram Gallic acid equivalent per gram of sample (g GAE/g) by multiplying by a factor of $3.02(4.53 \mathrm{ml} / 1.5 \mathrm{mg}$ ), where $4.53 \mathrm{ml}$ is the final medium volume used for analysis and $1.5 \mathrm{mg}$ is the weight of the sample in the medium.

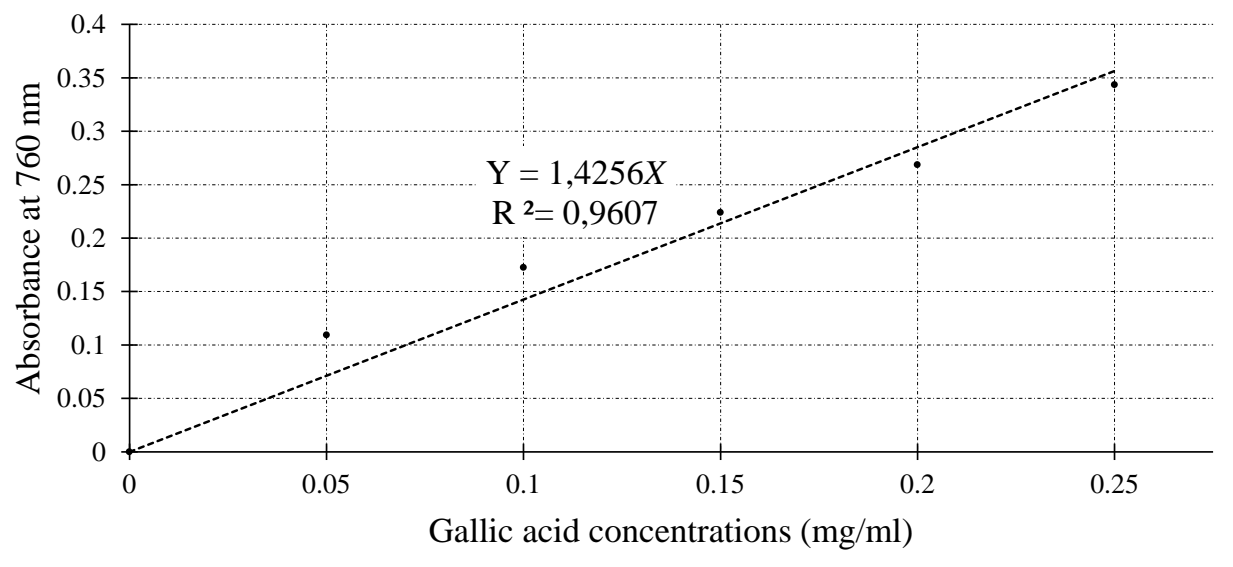

Figure 1. Calibration curve with Gallic acid at different concentrations for Polyphenols content determination

\subsection{Spectrophotometric Evaluation of Total Flavonoids}

The determination of total flavonoids was performed according to the method described by Marinova, Ribarova and Atanassova (2005). In a $25 \mathrm{ml}$ flask, $0.75 \mathrm{ml}$ of sodium nitrite $\left(\mathrm{NaNO}_{2}\right)$ at $5 \%(\mathrm{w} / \mathrm{v})$ was added to $2.5 \mathrm{ml}$ of extract. To the mixture, $0.75 \mathrm{ml}$ of aluminium chloride $\left(\mathrm{AlCl}_{3}\right)$ at $10 \%(\mathrm{w} / \mathrm{v})$ was added and then the whole was incubated for 6 minutes in the dark. Thereafter, $5 \mathrm{ml}$ of sodium hydroxide $(1 \mathrm{~N}, \mathrm{NaOH})$ were added, and the 
volume was completed to $25 \mathrm{ml}$. The preparation was vigorously shaken prior to assay of total flavonoids evaluation at $510 \mathrm{~nm}$ UV-visible spectrophotometer. A calibration curve $\left(\mathrm{R}^{2}=0.9976\right)$ was performed with Quercetin at different concentrations (Figure 2). The total flavonoids content was expressed in gram quercetin equivalent per litre of extract ( $\mathrm{g} \mathrm{QE} / \mathrm{l})$. The tests were performed in triplicate, on fresh or dried Pulp from 40 to $80^{\circ} \mathrm{C}$. The results can be converted into gram Quercetin equivalent per gram of sample (g QE/g) by multiplying by a factor of $0.2(25 \mathrm{ml} / 125 \mathrm{mg})$, where $25 \mathrm{ml}$ is the final medium volume used for analysis and $125 \mathrm{mg}$ is the weight of the sample in the final medium.

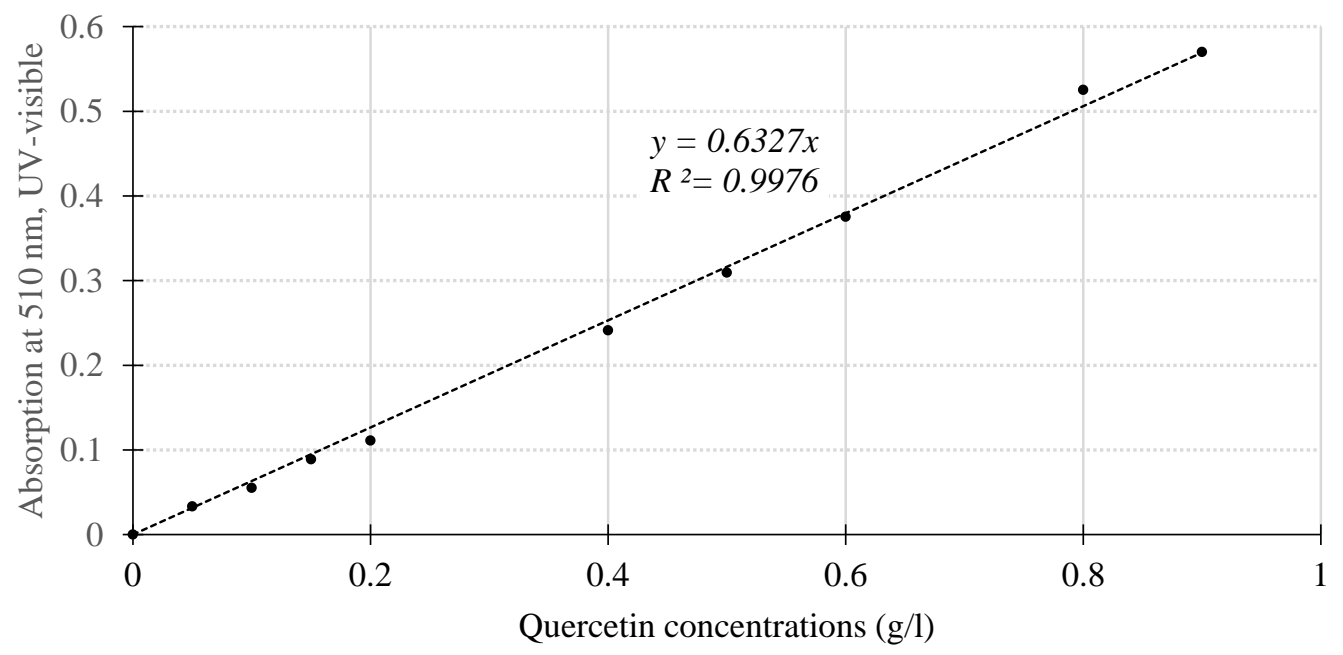

Figure 2. Calibration curve with quercetin at different concentrations, for Total Flavonoids Content determination

\subsection{Evaluation of Antioxidant Activity}

The antioxidant activity (AOA) was performed according to the method described by Teow et al. (2007). The radical cation $\mathrm{ABTS}^{*+}$ was produced by reaction of $8 \mathrm{mM}$. ABTS $(87.7 \mathrm{mg}$ in $20 \mathrm{ml}$ of distilled water) and $3 \mathrm{mM}$ of potassium persulfate $(0.0162 \mathrm{~g}$ in $20 \mathrm{ml}$ distilled water) in a ratio $1: 1(\mathrm{v} / \mathrm{v})$. The mixture was then incubated in the dark at room temperature for 12-16 hours. This $\mathrm{ABTS}^{*+}$ solution was diluted with methanol to obtain a solution whose absorbance was $0.7 \pm 0.02$ at $734 \mathrm{~nm}$. Thus, $3.9 \mathrm{ml}$ of diluted ABTS $^{*+}$ solution was added to 100 $\mu 1$ of the extract. After shaking, the mixture was incubated for 6 minutes in the dark $\left(\mathrm{T}=30 \pm 2^{\circ} \mathrm{C}\right)$. The residual absorbance of the radical ABTS ${ }^{*+}$ was then measured at $734 \mathrm{~nm}$ by visible-UV spectrophotometer and should be between $20 \%-80 \%$ of the absorbance of the blank. The tests were performed in triplicate and the results were expressed in micromole Trolox equivalent per litre $(\mu \mathrm{mol} \mathrm{TE} / \mathrm{l})$ of extract. The results can be converted into micromole Trolox equivalent per gram $(\mu \mathrm{mol} \mathrm{TE} / \mathrm{g})$ of sample extract by multiplying by a factor of 0.8 $(4 \mathrm{ml} / 5 \mathrm{mg})$, where $4 \mathrm{ml}$ is the final medium volume used for analysis and $5 \mathrm{mg}$ is the weight of sample in this solution. The activity of the compounds is expressed as Trolox equivalent (TE), corresponding to the concentration of Trolox, thus, the higher the TE value is, the higher the antioxidant is effective. For a calibration curve (Figure 3, $\mathrm{R}^{2}=0.9961$ ), the following concentrations of Trolox: $0.375 ; 0.5 ; 0.625 ; 1 ; 1.125 ; 1.375$; and 1.5 $\mu \mathrm{mol}$ were prepared and the rate of inhibition I (\%) $\mathrm{ABTS}^{*+}$ was expressed as follows:

$$
\left.\left.I(\%)=\left[\left[(A b s)_{\text {Control }}-(\text { Abs })_{\text {Extract }}\right)\right] /(\text { Abs })_{-} \text {Control }\right)\right] * 100
$$

Where: $\mathrm{Abs}_{\text {Control }}$ is the diluted ABTS absorbance, $\mathrm{Abs}_{\text {Extract }}$ is the diluted ABTS + Sample absorbance.

$$
\text { Extract concentration or Extract antioxidant activity }=(I(\%) * D F) / 4.9901
$$

The number 4.9901 stands for the slope of the standard Trolox line, and DF is the dilution factor. 


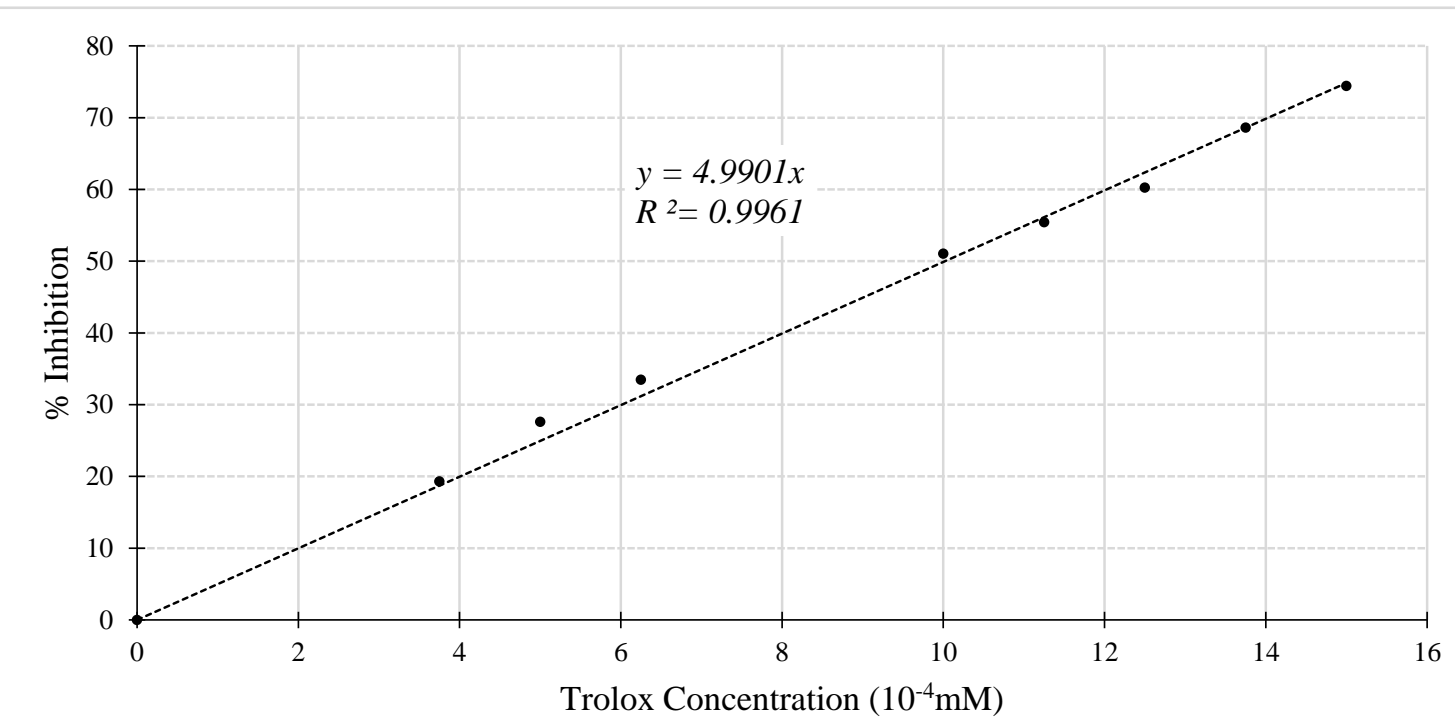

Figure 3. Calibration graph of Inhibition percentage related to Trolox concentration $\left(10^{-4} \mathrm{mM}\right)$ for antioxidant activity determination

\subsection{Statistical Analysis}

The data were submitted to a factorial analysis of variance (Two-ways, ANOVA), using XLSTAT 2014. The least squares means were separated according to Duncan's multiple range tests in a confidence interval of $99 \%$. The results were given in terms of interaction between two factors effect on the extracts.

\section{Results and Discussion}

\subsection{Total Phenols}

According to Marinova et al. (2005), polyphenols are a large group of phytochemicals in edible fruits. Additionally, Khadem and Marles (2010) reported that polyphenols molecule may have one aromatic ring, thus one phenol, or more leading to polyphenols. The changes observed from fresh pulp (product 0 ) to hot controlled air drying effect on the pulp are delivered on Figure 4.
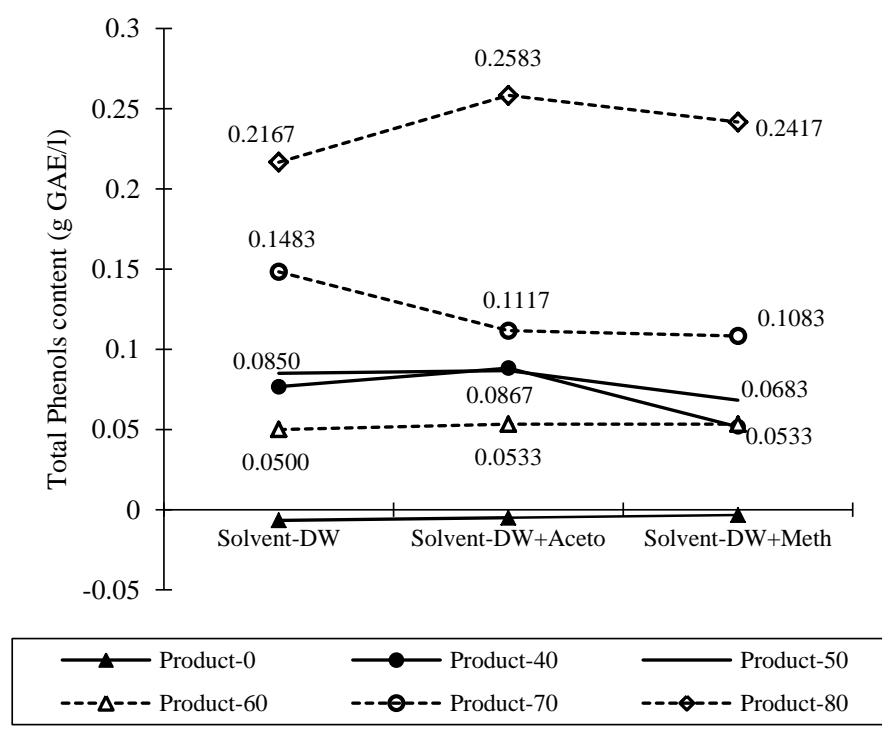

a.) Interaction between Product and Solvent

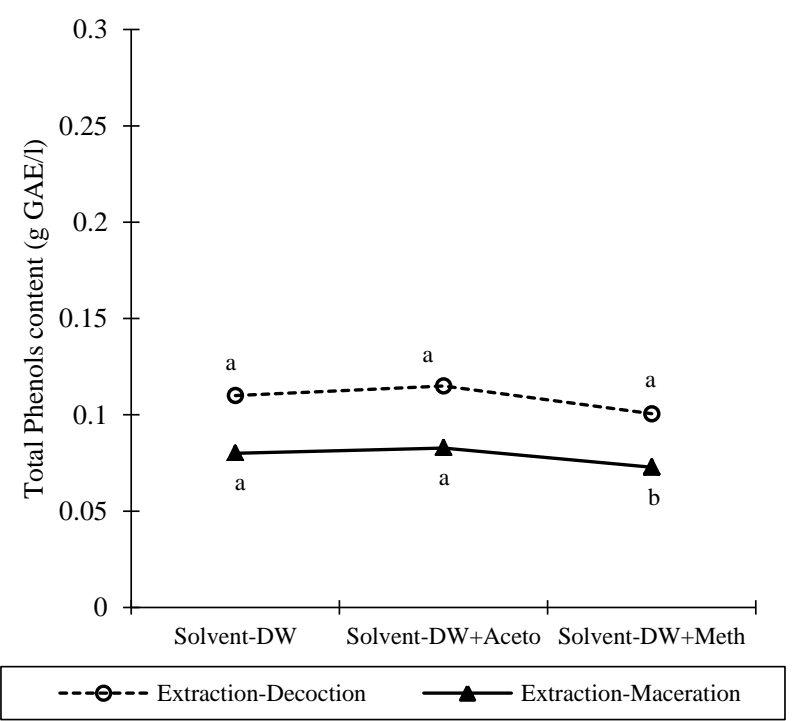

b.) Interaction between Extraction and Solvent 


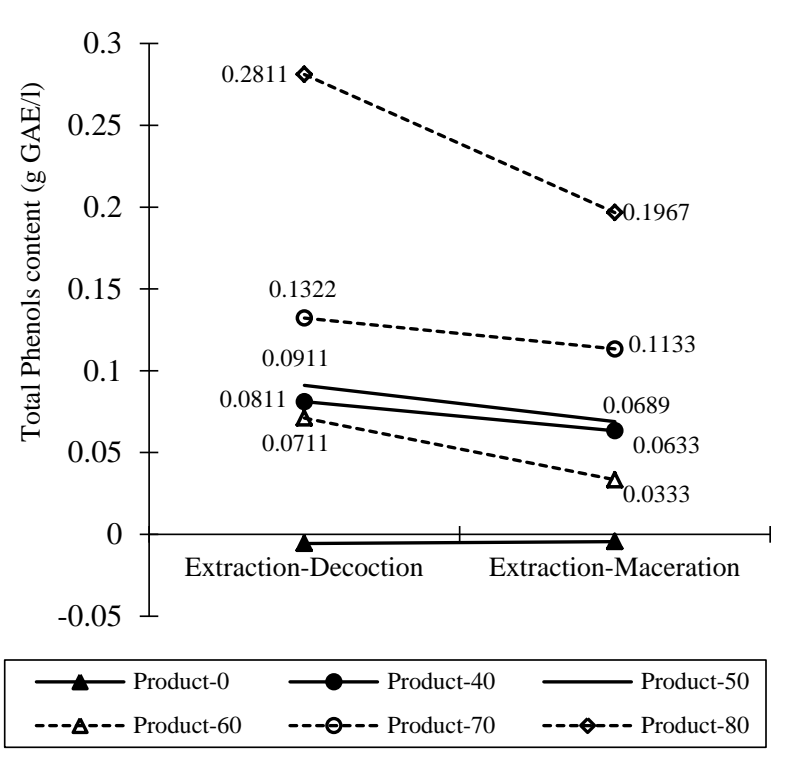

c.) Interaction between Product and Extraction

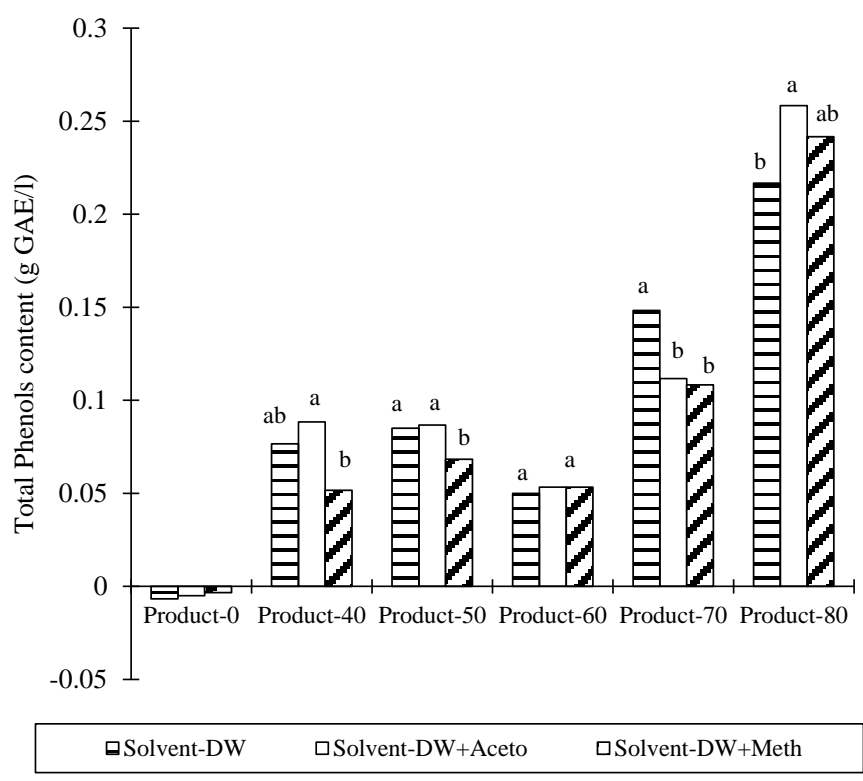

d.) Interaction between Solvent and Product

Figure 4. Factors interaction analysis between extraction modes (maceration, decoction), solvents (DW, DW+Meth, DW+Aceto) and Products (Fresh (0), 40, 50, 60, 70, 80 ${ }^{\circ} \mathrm{C}$ ) on Polyphenols content (g GAE/l). Different letters within a given product mean statistical difference by Duncan's multiple ranges at $\mathrm{p} \leq 0.01$

(Figure 4. b, d)

Using DW, DW+Meth and DW+Aceto as solvents on the first hand, the maceration and decoction as extraction modes on the second hand, no polyphenols compounds were found in the fresh pulp (Figure 4. a, c, d). Nonetheless this uncanny result, it doesn't mean the fresh pulp has no polyphenols effectively. In fact, even though the polyphenols, belonging to cell vacuoles, are said to be water soluble, Wood et al. (2002) recalled that some flavonoids can bind to proteins. Moreover, they came to the point that basic medium $(\mathrm{pH}=8)$ is potent than distilled water and acidic medium as solvents for polyphenols extraction. Simultaneously, the $30 \mu 1$ of the extract used for the assessment of total polyphenols may be too little, because of the high water content in the fresh product. Due to the high content of protein in Elaeis guineensis pulp between, this may be the reason why Rodríguez et al. (2016) used 50 $\mu 1$ of the extract for total phenols assessment, instead of $30 \mu 1$, on raw sample. They extracted $0.263 \mathrm{mg} \mathrm{GAE} / \mathrm{g}$ on fresh hybrid palm oil. The palm yellow or yellow-orange colour fruits may contain an important amount of polyphenols. For instance, Gil, Francisco, Barberan, Pierce and Kader (2002) extracted important amounts of polyphenols from fresh fruit fleshes. In arctic star white and red jim flesh, they extracted 0.154 and $0.415 \mathrm{mg} \mathrm{GAE} / \mathrm{g}$ respectively; demonstrating that the colour is a key factor. Equally important, some colourful foodstuff pulps such as yellow or purple fleshed sweet potatoes exhibit very good amount of phenols. In this case, Karin yellow flesh exhibited 3.44 and valfi purple flesh $4.81 \mathrm{mg}$ GAE/g (Lachman et al., 2008). In addition, cactus pear fruits' pulp, Opuntia ficus-indica, has 0.892 for the purple colour and $0.698 \mathrm{mg} \mathrm{GAE} / \mathrm{g}$ for the yellow one on fresh matter (Albano et al., 2015). Working on Nectarine, Peach, and Plum, Gil et al. (2002) came to the conclusion that peels generally contain more total phenols than fleshes. Considering red jim, they got 1.403 in peels and $0.415 \mathrm{mg} \mathrm{GAE} / \mathrm{g}$ in flesh. Similarly, at a fully ripe stage, Tacinga inamoena showed 3.4895 in peels and $0.2867 \mu \mathrm{g} / \mathrm{g}$ in pulp for total carotenoids content (Dantas et al., 2016). For coloured fruits, the natural barriers between the content and the atmosphere, the peels exhibit better total phenols content than the pulps.

Also, according to Saleh, Tawfik and Tarboush (2011), phenols content determined by Folin-Ciocalteu method could be affected by protein, ascorbic acid, and reducing sugars in the medium. Indeed, Ali et al. (2010c) found that B. aethiopum Mart pulp contains more than $0.22 \mathrm{~g}$ of total sugars, $0.04 \mathrm{~g}$ of crude protein, and an important amount of ascorbic acid (vitamin C) in a gram of either fresh or dried pulp at $40^{\circ} \mathrm{C}$ during 48 hours. Again, Vijayakumari, Vengaiah and Kiranmayi (2014), replicating Ali et al. (2010c) experiment on B. flabellifer pulp powder in Asia, found $0.225 \mathrm{~g}$ of total sugars, $0.0124 \mathrm{~g}$ of protein, and $0.016 \mathrm{mg}$ of ascorbic acid in a gram of dried pulp. So, in the working conditions, total phenols assessment could have been severely affected. Thus the 
conditions were not met for polyphenols extraction on B. aethiopum fresh pulp (Product-0).

On dried products, looking at the interaction between the solvents and the products (Figure 4. a, d), from 40 to $60^{\circ} \mathrm{C}$, numerical differences were observed, and these results were sometimes significantly different at Duncan multiple means comparison at $99 \%$ interval of confidence, in a given product. At $40^{\circ} \mathrm{C}$, the maximum extract was obtained in DW+Aceto with 0.0883 (266.667), then it dropped to $0.0867\left(261.834\right.$ ) at $50^{\circ} \mathrm{C}$ and ended at $0.0533 \mathrm{~g} \mathrm{GAE} / \mathrm{l}(160.966 \mathrm{mg} \mathrm{GAE} / \mathrm{g})$. Similarly, when M. oleifera seeds were dried around 50 and $55^{\circ} \mathrm{C}$, extracted with aqueous methanol (their best solvent extractor), total phenols extracts were $49.53 \mathrm{mg} \mathrm{GAE} / \mathrm{g}$ (Singh, Negib, \& Radha, 2013), which were 4.16 times lower than B. aethiopum extracts at $50^{\circ} \mathrm{C}$ in DW+Meth (0.0683 g GAE/l, $206.266 \mathrm{mg} \mathrm{GAE} / \mathrm{g}$ ), the worst extractor. Singularly, the $60^{\circ} \mathrm{C}$ product line (Figure $4 . \mathrm{a}$ ), resulting from solvents effect, appeared almost flat. This product presented a steady point (Figure 4. d), with a minimum extract of 0.05 (151) in DW and a maximum of $0.0533 \mathrm{~g} \mathrm{GAE} / 1$ (160.966 mg GAE/g) in DW+Aceto and DW+Meth, respectively. The observed gap was just $0.0033 \mathrm{~g} \mathrm{GAE} / 1$ (9.966 mg GAE/g), meaning 6.6\%. Madrau et al. (2009) argued that during low drying temperatures from 55 to $60^{\circ} \mathrm{C}$, in presence of oxygen, it occurs a polyphenoloxydase (PPO) enzymatic activity. Thus, since low drying temperature requires longer drying periods compare to high temperature, the resulting polyphenols content slows down. These findings corroborate our results since above $60^{\circ} \mathrm{C}$ the total phenols content increased quickly.

Since the solvent DW+Aceto leaded to higher extractions (Figure 4.d) above $70^{\circ} \mathrm{C}$, we followed its variations from 60 to $80^{\circ} \mathrm{C}$. From $60(0.0533)$, via $70(0.1117)$ to $80^{\circ} \mathrm{C}(0.2583 \mathrm{~g} \mathrm{GAE} / \mathrm{l})$ the extraction effectiveness grown for 109.57 and $384.62 \%$ respectively at 70 and 80 from $60^{\circ} \mathrm{C}$. Duncan multiple means comparison at $99 \%$ interval of confidence showed differences at $70^{\circ} \mathrm{C}$. Illustrated on figure 4. d, DW extracted $0.1483 \mathrm{a} \mathrm{g} \mathrm{GAE} / 1$ (447.866 mg GAE/g), and this amount was statistically higher from the results of DW+Aceto $(0.1117 \mathrm{~b} \mathrm{~g} \mathrm{GAE} / \mathrm{l}$; $337.334 \mathrm{mg} \mathrm{GAE} / \mathrm{g})$ and DW+Meth $(0.1083 \mathrm{~b} \mathrm{~g} \mathrm{GAE} / \mathrm{l} ; 327.066 \mathrm{mg} \mathrm{GAE} / \mathrm{g})$, which were non-significant to each other. For example, from dried grape at $70^{\circ} \mathrm{C}$ during 100 hours, Rajha et al. (2014) extracted $4.92 \mathrm{mg}$ GAE/g of total phenols. Thus, B. aethiopum Mart pulp is greatly richer, 91.03 times, than grape for total phenols content. Beside ligneous vegetables, edible mushrooms are said to be very good sources of polyphenols. To illustrate, Wandati, Kenji and Onguso (2013) dried at $70^{\circ} \mathrm{C}$ a large variety of mushrooms, extracted them in aqueous ethanol, and the highest extract of total phenols was $15.8 \mathrm{mg} \mathrm{GAE} / \mathrm{g}$. Herein, the least extraction was $0.1083 \mathrm{~g}$ GAE/l (327.066 mg GAE/g) in DW+Meth.

At high temperature, following Madrau et al. (2009) remarks, the PPO enzymatic reaction doesn't occur because of a relative short exposure time. In addition, Lohani and Muthukumarappan (2015) indicated that the phenolic compounds can be liberated by heat treatment, and moreover, Jeong et al. (2004) came to the conclusion that phenols should have different bound status along with plant species. In accordance with Lohani and Muthukumarappan (2015), compare to raw material, dried products exhibit higher phenolic compound extracts. For example, the fresh exhibited 3.125 versus $3.5 \mathrm{mg}$ GAE/g for the dried apple pomace at $50^{\circ} \mathrm{C}$. Furthermore, they found that, when the product is fermented then dried, it exhibits higher total phenols extracts. Despite the advantage provided by fermentation, their findings were still lower than B. aethiopum extractions at the same drying temperature. Herein, the extracts were 256.7, 261.834 and $206.266 \mathrm{mg} \mathrm{GAE} / \mathrm{g}$ respectively in DW, $\mathrm{DW}+$ Aceto and DW+Meth. Thus B. aethiopum is richer than apple pomace for total phenols. In fact, at high drying temperature, the covalent bound in phenolic compounds can be cleaved (Lohani \& Muthukumarappan, 2015). Many authors reported that an increase drying temperature leads to an increase total phenolic extract (Wood et al., 2002; Jeong et al., 2004; Ruenroengklin et al., 2008; Madrau et al., 2009). However, Rajha et al. (2014) mentioned that, at high drying temperature, when the product reaches a constant weight, meaning it can't release any more water, we should stop heating; otherwise the excessive heat leads to a degradation of polyphenols. The factorial analysis revealed that the drying temperature (fresh, 40, 50, 60, 70 and $80^{\circ} \mathrm{C}$ ) (Figure 4. a, c) and the extraction mode (decoction or maceration) (Figure 4. c) had each a main effect on total phenols extraction. In contrary, when the extraction mode is set, the solvents (DW, DW+Meth and DW+Aceto) (Figure 4. b) extracts were not statistically different in decoction. Additionally, with maceration, no deep slop was observed, then both curves were almost parallel. Thus solvents were not main effects for polyphenols extraction.

In the frame of our experiments, the best total phenols extracts were reached at $80^{\circ} \mathrm{C}$, through decoction in DW+Aceto and DW+Meth, for 0.2583a (780.06) and 0.2417ab g GAE/l (729.934 mg GAE/g) respectively. Taking into account the colour changes, from 40 to $80^{\circ} \mathrm{C}$, we may deduct that $80^{\circ} \mathrm{C}$ is an excessive heating temperature. Initially, at 40 and $50^{\circ} \mathrm{C}$, the obtained flour was quite white colour, and at $60^{\circ} \mathrm{C}$ the colour changed to a light chocolate. Then, with an intensification of the chocolate colour, the flour colour looked nicer at $70^{\circ} \mathrm{C}$. Finally, at $80^{\circ} \mathrm{C}$ the product turned to intense brown colour, maybe due to the high content of sugars which were probably caramelizing. To be more exact, looking at phytochemicals content in B. flabellifer dried pulp at $60^{\circ} \mathrm{C}$ 
during 48 hours, Vijayakumari et al. (2014) found that it contained 22.5\% of sugars; when Ali et al. (2010c) reported $23.965 \%$ in $B$. aethiopum dried pulp at $40^{\circ} \mathrm{C}$ for the same drying time. Since the extraction in DW through decoction was more efficient at 70 than $40^{\circ} \mathrm{C}$, respectively 0.1485 (447.866) versus $0.0767 \mathrm{~g}$ GAE/l (231.634 mg GAE/g), meaning an improvement of $93.61 \%$ from $40^{\circ} \mathrm{C}$, we admitted $70^{\circ} \mathrm{C}$ as the best drying temperature, because in addition it reduced the drying period from 8 to 5 days.

\subsection{Total Flavonoids}

Admittedly, flavonoids are part of polyphenols (Rajha et al., 2014); therefore, some researchers use indirect ways to determine total flavonoids content when they have total phenols. In that case, they induce the precipitation of flavonoids by formaldehyde, then using again Folin-Ciocalteu method they assess the non-flavonoids compounds. Unlike Rajha et al. (2014) findings on grape by-products, the temperature had certainly a positive effect on total phenols and flavonoids extraction, but not a linear one. Herein, total flavonoids extractions did depend on the drying temperature, solvent and extraction mode. Beginning with the fresh product (Figure 5. e), we got the best extractions in DW and DW+Aceto; 0.115a (23) and 0.1133a g QE/l (22.66 mg QE/g) respectively, and these results were not statistically different. But they were statistically different from $0.0667 \mathrm{~b} \mathrm{~g} Q \mathrm{QE} / \mathrm{l}(13.34$ $\mathrm{mg}$ QE/g), the amount extracted with DW+Meth. Regarding DW+Meth, the extraction wasn't good, since compare to DW, $42.61 \%$ of extraction power was lost. Likewise, Karimi et al. (2015) works on oregano fresh leaves showed that total flavonoids content averages in cultivars Mexican (Lippia graveolens) and Mediterranean (Origanum vulgare) were 82.744 and $41.973 \mathrm{mg} / \mathrm{g}$, respectively. In Lippia graveolens, the richest cultivar, they found $1.636 \mathrm{mg} \mathrm{QE} / \mathrm{g}$, and this amount is more than 8 times inferior to the lowest extraction with DW+Meth on B. aethiopum fresh pulp. Herein, following with the drying temperature effect, DW as solvent, the 40,50 , and $60^{\circ} \mathrm{C}$ dried products allowed the extractions of 0.5083 (101.66), 0.3967 (79.34) and $0.1883 \mathrm{~g} \mathrm{QE} / 1$ (37.66 mg QE/g), respectively (Figure 5. e, h).

These findings contrasted with Rajha et al. (2014) results, since from 40 to $60^{\circ} \mathrm{C}$ the extracts decreased while drying temperatures increased. Thus, moderate temperatures such as 40 and $50^{\circ} \mathrm{C}$ allowed better extractions than $60^{\circ} \mathrm{C}$. Hence, with DW, from 40 to $60^{\circ} \mathrm{C}$, the extracts decreased about $62.95 \%$. At $50^{\circ} \mathrm{C}$, the best extraction of $0.4783 \mathrm{~g} \mathrm{QE} / 1$ (95.66 mg QE/g) was achieved in DW+Aceto. Whereas DW leaded to very sensible results (Figure 5. e) in relation with each product, DW+Meth looked like a stable buffer for $40,50,60$ and $70^{\circ} \mathrm{C}$ products. For instance, in DW, total flavonoids extracts moved from the highest 0.5083 at $40^{\circ} \mathrm{C}$ to the lowest $0.1883 \mathrm{~g} \mathrm{QE} / \mathrm{l}$ at $60^{\circ} \mathrm{C}$, thus the gap was $0.32 \mathrm{~g} Q E / 1$, which represented $62.955 \%$ of losses. The extracts of 50 and $70^{\circ} \mathrm{C}$ products were lying in between. In contrary, in DW+Meth, the results were grouped from 40 to $70^{\circ} \mathrm{C}$ in a narrow interval, from $0.2833 \mathrm{~b} \mathrm{~g} \mathrm{QE} / 1\left(56.66 \mathrm{mg} \mathrm{QE} / \mathrm{g}\right.$, the highest at $\left.50^{\circ} \mathrm{C}\right)$ to $0.2583 \mathrm{c} \mathrm{g} \mathrm{QE} / 1(51.66 \mathrm{mg} \mathrm{QE} / \mathrm{g}$, the lowest at $\left.70^{\circ} \mathrm{C}\right)$. The difference is $0.025 \mathrm{~g} \mathrm{QE} / 1$, which is twelve times lower than $0.32 \mathrm{~g} \mathrm{QE} / 1$. The fresh $(0)$ and the driest product $\left(80^{\circ} \mathrm{C}\right)$ appeared as out layers with 0.0667 (13.34) and $0.3667 \mathrm{~g} \mathrm{QE} / 1$ (73.34 mg QE/g), respectively. When B. aethiopum pulps are dried between 40 and $60^{\circ} \mathrm{C}$, aqueous methanol may not be a good medium for total flavonoids assessment.

Looking at the interaction between the products and the extraction modes (Figure 5. g), the curve obtained at $40^{\circ} \mathrm{C}$ presented the deepest slop from decoction to maceration, where the minimum and maximum were 0.3056 (61.12) and $0.4833 \mathrm{~g} \mathrm{QE} / \mathrm{l}(96.66 \mathrm{mg} \mathrm{QE} / \mathrm{g})$ respectively; so the slop was $+58.148 \%$ from the origin. Thus, the extraction mode was a main effect for total flavonoids content assessment at $40^{\circ} \mathrm{C}$, whereas it wasn't for other products. The announced PPO enzymatic reaction by Madrau et al. (2009), occurring during the long exposure at low temperatures may not affect flavonoid compounds in B. aethiopum Mart mature pulp, since they are still available. Or, maybe our drying method which consisted in a thin layer of fibrous pulp in the oven leaded to a quick dry to reach the stable weight, so that the phenomenon was eschewed. The best drying temperature for getting the best total flavonoids extract was $40^{\circ} \mathrm{C}$, and maceration was the best extraction mode in DW (Figure 5 . f). Flavonoids are also known as Vitamin P, that the plants synthetize to produce yellow and other pigments, and they play important anti-inflammatory, anti-allergic and anti-cancer activities in human body. Because of these health benefits, many researches check for the presence of this phytochemical in daily consumed vegetables. 

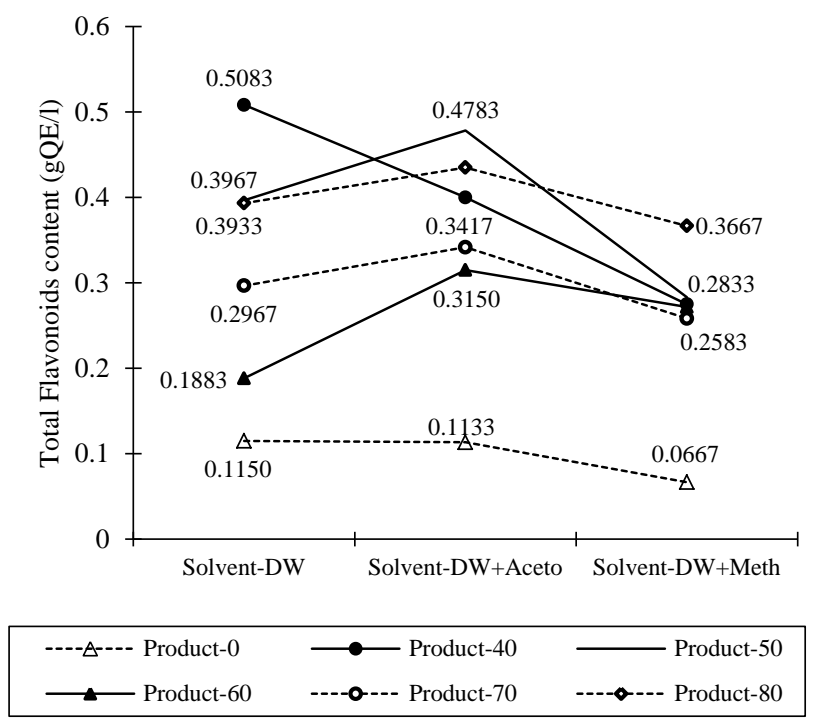

e.) Interaction between Product and Solvent

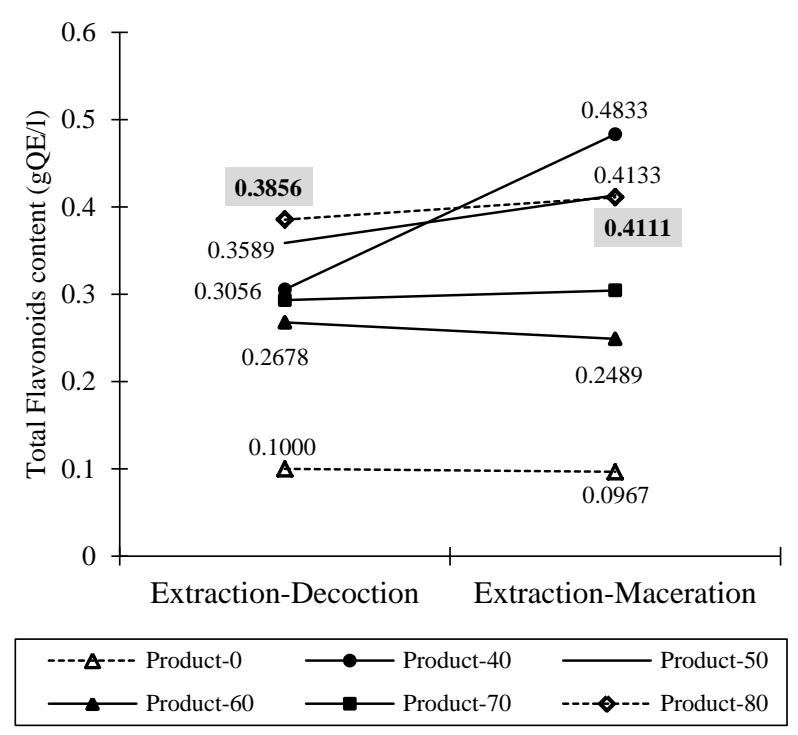

g.) Interaction between Product and Extraction

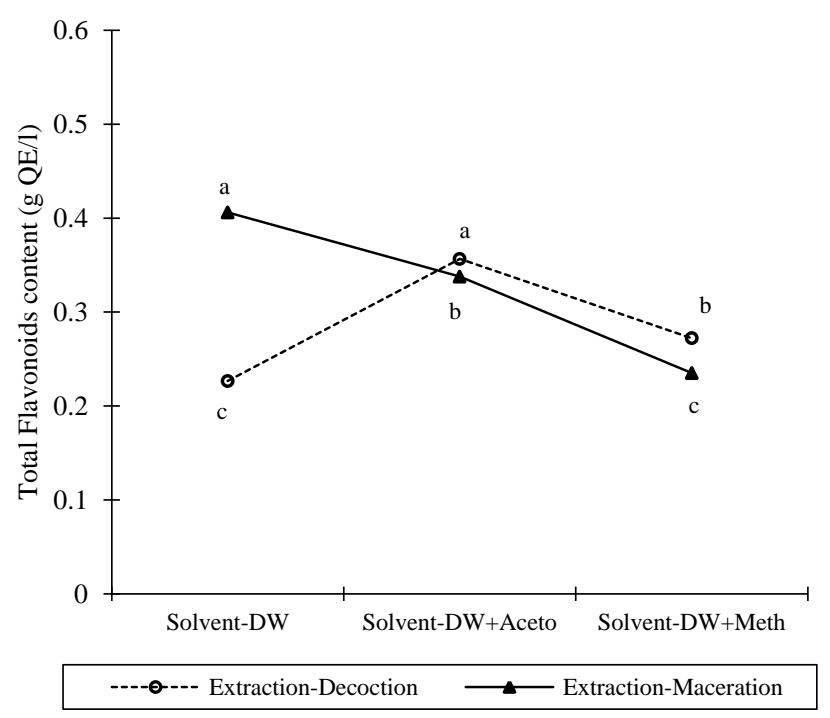

f.) Interaction between Extraction and Solvent

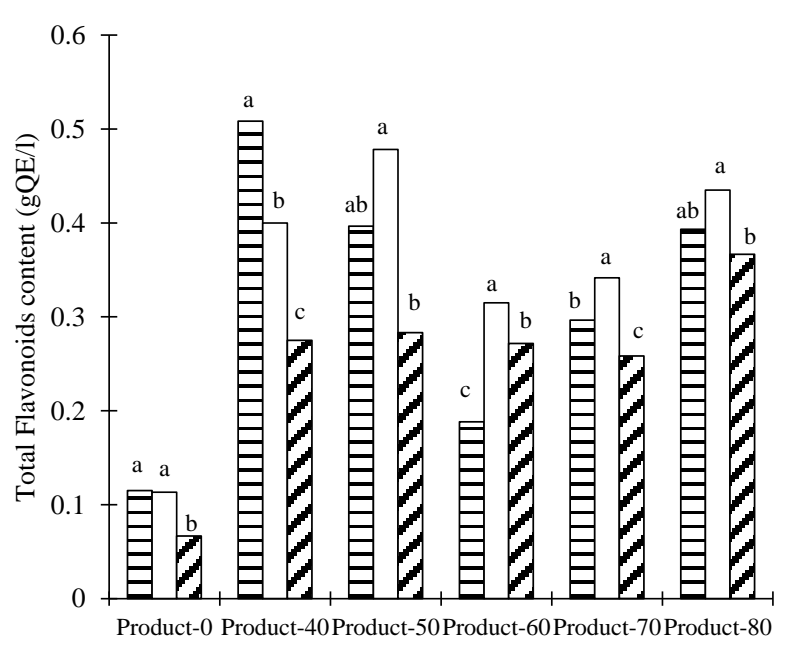

घSolvent-DW $\square$ Solvent-DW+Aceto $\quad$ aSolvent-DW+Meth

h.) Interaction between Solvent and Product

Figure 5. Factors interaction analysis between extraction modes (maceration, decoction), solvents (DW, DW+Meth, DW+Aceto) and Products (fresh $(0), 40,50,60,70,80^{\circ} \mathrm{C}$ ) on flavonoids content (g QE/l). Different letters within a given product column mean statistical difference by Duncan's multiple ranges at $\mathrm{p} \leq 0.01$ (Figure

$$
\text { 5. } \mathrm{f}, \mathrm{h} \text { ) }
$$

Due to its closeness to "under the sun" conditions in rural areas, $40^{\circ} \mathrm{C}$ is preferred by Ali et al. (2010a) and Vijayakumari et al. (2014) during the assessment of functional food phytochemicals. Better, Moyo, Oyedemi, Masita and Muchenje (2012) dried M. oleifera leaves under shade at room temperature, then they assessed total flavonoids contents. The leaves powder extracted with aqueous acetone exhibited $295.01 \mathrm{mg} \mathrm{QE} / \mathrm{g}$, whereas distilled water extracts were relatively poor, $45.1 \mathrm{mg} \mathrm{QE} / \mathrm{g}, 7.55$ times lower. Extracted with distilled water, $B$. aethiopum pulp dried at $40^{\circ} \mathrm{C}$ exhibited $101.66 \mathrm{mg} \mathrm{QE} / \mathrm{g}$, and this amount is 2.9 times lower than $295.01 \mathrm{mg}$ QE/g (Moyo et al., 2012). Again, along with total phenols analysis, Wandati et al. (2013) checked for total flavonoids content in mushroom dried at $70^{\circ} \mathrm{C}$. They remarked that young fruits had higher total flavonoids content than mature fruits, 11.2975 versus $8.9087 \mathrm{mg}$ QE/g respectively. Precisely, the best extraction was obtained from caps, $15.1108 \mathrm{mg} \mathrm{QE} / \mathrm{g}$. At $70^{\circ} \mathrm{C}$ drying temperature, B. aethiopum mature pulp exhibited 68.34 $\mathrm{mg} \mathrm{QE} / \mathrm{g}$, thus, B. aethiopum pulp is richer than some mushrooms. In short, considering $B$. aethiopum pulp, from fresh to $40^{\circ} \mathrm{C}$ dried product, DW may be the best solvent for total flavonoids assessment through maceration in 
comparison to alcoholic solvents. But, above $40^{\circ} \mathrm{C}$ an aqueous $70 \%$ acetone may lead to better assessments than distilled water. The best drying temperature for total flavonoids assessment was $40^{\circ} \mathrm{C}$. Due to the observed deep slops (Figure 5. e, f, g), the three factors which were extraction mode, drying temperature and extraction were main effects for the total flavonoids extracts $(p<0.0001)$. Since the total phenols composed by flavonoid and non-flavonoid compounds do all contribute to functional foods effect in human body, we assessed at the last step, the derived antioxidant activity.

\subsection{Antioxidant activity $\left(\right.$ ABTS $\left.^{*}+\right)$}

The importance of antioxidants in human body has been recalled many times. In fact, on 1996, through a review, Halliwell (1996) mentioned that antioxidants are needed to scavenge and prevent the formation of reactive oxygen species, such as superoxide $\left(\mathrm{O}_{2}{ }^{\bullet}\right)$, hydroxyl $\left(\mathrm{OH}^{-}\right)$, peroxyl $\left(\mathrm{RO}_{2}{ }^{\bullet}\right)$, alkoxyl $\left(\mathrm{RO}^{\bullet}\right)$, and many reactive nitrogen species like nitronium cation $\left(\mathrm{NO}_{2}^{+}\right)$, peroxynitrous acid $\left(\mathrm{ONOO}^{-}\right)$and many others. These anions or cations presence in our body can induce serious damages. Fortunately, the antioxidants fight against these damageable systems. Antolovich, Prenzler, Patsalides, McDonald and Robards (2002) defined an antioxidant as "any substance that, when present at low concentrations, compared with those of the oxidizable substrate, significantly delays or inhibits oxidation of that substrate". So, these substances either prevent or repair these damages. Along with our body metabolism, many $\mathrm{OH}^{-}$scavengers have a high rate constant, higher than 1010/(M*Sec) (Halliwell, 1996). Among many ways to assess antioxidants in diets, Awika, Rooney, Wu, Prior, and Zevallos (2003) highlighted the fact that 2, 2'-azinobis-3-ethylbenzothiazoline-6-suslfonic acid (ABTS) is inexpensive and easy to use and above all, it's stable to $\mathrm{pH}$. Similarly, Prior, Wu and Schaich (2005) preferred using $\mathrm{ABTS}^{*+}$ radical because it's intensively coloured and then assessing antioxidant capacity can easily be measured as the ability of the compounds to decrease the colour by reacting directly with the ABTS ${ }^{*+}$ radical. Above these two important aspects (inexpensive and easy to use), working on sorghum and sorghum products, Awika et al. (2003) found that compare to 2, 2-diphenyl-1-picrylhydrazyl (DPPH), using $\mathrm{ABTS}^{*+}$ cation requires least lasting time for the medium preparation. Furthermore, $\mathrm{ABTS}^{*+}$ was more efficient than DPPH on sorghum bran antioxidant assessment. This efficacy of $\mathrm{ABTS}^{*+}$ cation was observed by Candrawinata, Golding, Roach and Stathopoulos (2014) who worked on apple pomace, since extracting at $70^{\circ} \mathrm{C}$ for $60 \mathrm{~min}$, the antioxidant activity went from 746.9 with DPPH to $1354.45 \mu \mathrm{gTE} / \mathrm{g}$ with $\mathrm{ABTS}^{*+}$, it means an increase of $81.34 \%$.

Aware of such advantages, we used ABTS, and applied it on six different drying temperature products, with three solvents and two extraction modes. Additionally, in the following discussion, all the cited works were performed with $\mathrm{ABTS}^{*+}$ cation. In these investigation combined conditions, the effects of interactions were assessed and the Figure 6 resumes the results. The fresh product exhibited the lowest antioxidant activity (AOA) (Figure 6. i, 1), opposed to the driest $\left(80^{\circ} \mathrm{C}\right)$ which allowed the highest; for instance, in DW+Aceto, AOAs were $0.1269(0.10152)$ versus $1.088 \mu \mathrm{mol} \mathrm{TE} / \mathrm{l}(0.8704 \mu \mathrm{mol} \mathrm{TE} / \mathrm{g})$ respectively (Figure 6. 1). After homogenizing pulp and peel of guava (Psidium guajava), Thaiphong, Boonprakob, Crosby, Zevallos and Byrne (2006) assessed the antioxidant activity on one white fleshed "Allahabad Safeda" and three pink-fleshed whose were "Fan Retief", "Ruby Supreme" and an "advanced selection" extracted with methanol, and the AOAs were 37.9, 34.4, 22.3, 29.6 $\mu \mathrm{mol} \mathrm{TE} / \mathrm{g}$ respectively. In our investigation, the methanol extracts AOA was $0.0874 \mu \mathrm{mol} \mathrm{TE} / \mathrm{l}(0.06992 \mu \mathrm{mol}$ $\mathrm{TE} / \mathrm{g}$ ) on fresh product. Moreover, on Opuntia ficus-indica fresh pulp, Albano et al. (2015) detected 6.1 and 3.7 $\mu \mathrm{mol} \mathrm{TE} / \mathrm{g}$ on purple and orange colour respectively. It appears that, any colour of Opuntia ficus-indica or guava fresh material may have a better antioxidant activity than B. aethiopum Mart. Again on fresh weight basis, Awika et al. (2003) proved that the colour factor is important for total phenols, thus, and antioxidant activity deliveries. To be exact, by extracting with 70\% aqueous acetone, on one hand, white and red grains exhibited 6 and $53 \mu \mathrm{mol}$ $\mathrm{TE} / \mathrm{g}$; and on the second hand, white and red brans delivered 28 versus $53 \mu \mathrm{mol} \mathrm{TE} / \mathrm{g}$ respectively. Similarly, Teow et al. (2007) found that orange and dark orange had 5.89-10.3 versus $18.2 \mu \mathrm{mol} \mathrm{TE} / \mathrm{g}$ correspondingly. On the same way, Rodriguez et al. (2016) found that 18 weeks after anthesis, hybrid palm oil from Elaeis oleifera $\times$ Elaeis guineensis had $0.59 \mu \mathrm{mol} \mathrm{TE} / \mathrm{g}$ of extract, demonstrating that palm oils have good properties for health benefits. In this study, a broad ascertainment could be made, such as, from fresh up to $60^{\circ} \mathrm{C}$, acetone extracted better than methanol. The same phenomenon was observed on total phenols curve (Figure 4. d). Whereas above $60^{\circ} \mathrm{C}$ methanol took over. For instance, many authors looked for soft drying temperatures, in the aim to keep all phytochemicals intact in the cells. Using lower temperature than Ali et al. (2010c), Arunachalam, Saravanan and Parimelazhagan (2011) dried the non-germinated seed embryo of $B$. flabellifer under shade at room temperature, $25^{\circ} \mathrm{C}$. 


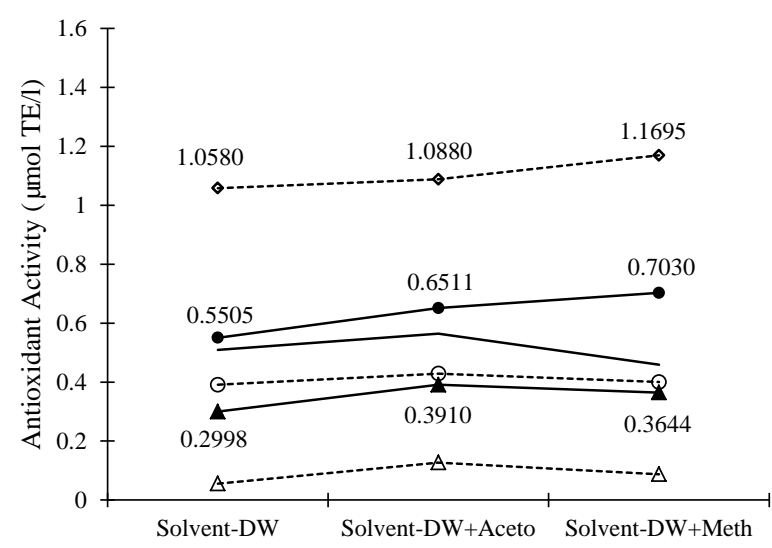

\begin{tabular}{|c|c|c|}
\hline ---A--- Product-0 & $---\odot---$ Product-40 & $\longrightarrow$ Product -50 \\
\hline$\longrightarrow$ Product-60 & $\longrightarrow$ Product-70 & ---- $\diamond---$ Product- 80 \\
\hline
\end{tabular}

i.) Interaction between Products and Solvents

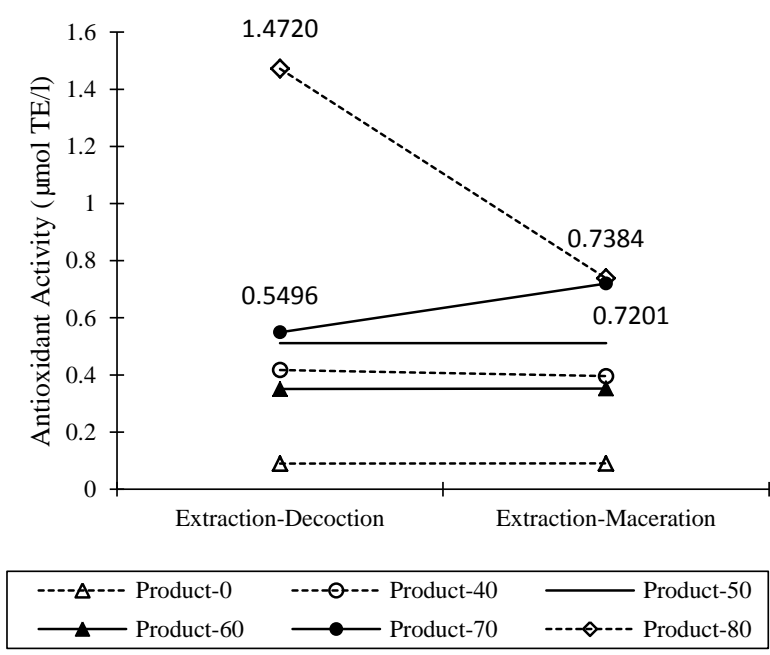

k.) Interaction between Products and Extraction modes

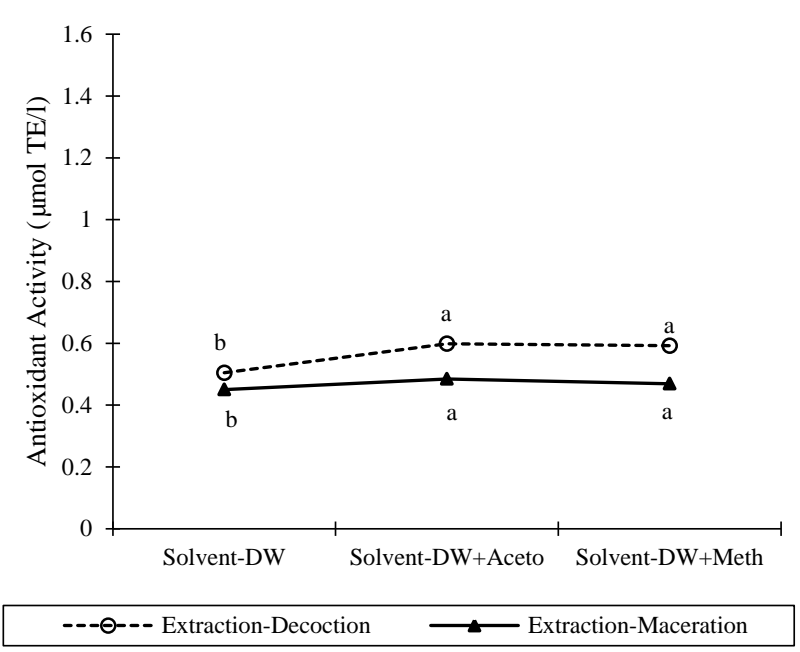

j.) Interaction between Extraction modes and Solvents

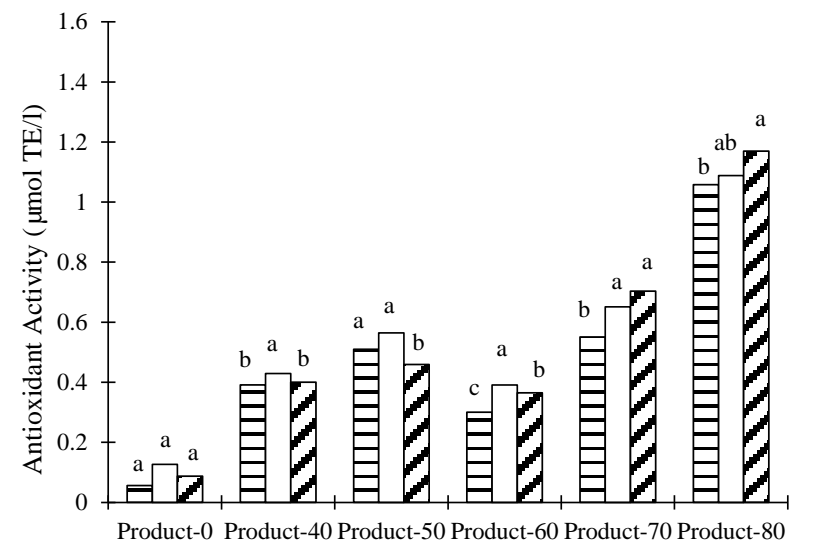

घSolvent-DW $\square$ Solvent-DW+Aceto $\quad$ Solvent-DW+Meth

1.) Interaction between Solvents and Products

Figure 6. Factors interaction analysis between extraction modes (maceration, decoction), solvents (DW, DW+Meth, DW+Aceto) and Products $\left(0,40,50,60,70,80^{\circ} \mathrm{C}\right)$ on antioxidant activity $(\mu \mathrm{mol} \mathrm{TE} / \mathrm{l})$. Different letters within a given product column mean statistical difference by Duncan's multiple ranges at $\mathrm{p} \leq 0.01$ (Figure

$$
\text { 6. j, 1) }
$$

Effectively, the AOAs were tremendously higher than those herein findings, since they reported 5206.9 and $3438.8 \mu \mathrm{mol} \mathrm{TE} / \mathrm{g}$, respectively for aqueous acetone and methanol. Apart 70 and 80 , both extraction modes gave almost equal results on fresh, 40,50 and $60^{\circ} \mathrm{C}$ products, leading to parallel lines to the abscise' one (Figure $6 . \mathrm{k}$ ). Also on Figure 6. j, the interaction between the extraction modes (decoction and maceration) and the solvents (DW, DW+Aceto, DW+Meth) showed that for a given extraction mode, DW+Aceto and DW+Meth resulted to non-significant different results, and DW extracted always the lowest quantity which was significantly different from the previous $(\mathrm{p} \leq 0.01)$. Thus, the main effect on AOA was the drying temperature for 70 and $80^{\circ} \mathrm{C}$, their lines' slops were deeper than the others. So, considering the solvents, the present outputs fitted to Arunachalam et al. (2011) results at $25^{\circ} \mathrm{C}$ since aqueous acetone and methanol had the highest extractions (Figure 6. 1). Alike the phenomenon observed during polyphenols assessment, at $60^{\circ} \mathrm{C}$ we got the same depressed results. Thus, breaking the increasing tendency, altogether the three bars dropped (Figure 6. 1). Looking at $50^{\circ} \mathrm{C}$, the highest AOA with DW+Aceto decreased from 0.5645 (0.4516) to $0.3910(0.3128)$ and the lowest extract 0.4593 (0.36744) with DW+Meth dropped to $0.3644 \mu \mathrm{mol} \mathrm{TE} / \mathrm{l}(0.29152 \mu \mathrm{mol} \mathrm{TE} / \mathrm{g})$. This depression at $60^{\circ} \mathrm{C}$ was reported on grape by-products, when Rajha et al. (2014) assessed the AOA from 40 to $80^{\circ} \mathrm{C}$. In contrary, from 20 
to $80^{\circ} \mathrm{C}$, Candrawinata et al. (2014) found that an increasing temperature permitted an increasing extraction of total phenols, thus an increasing antioxidant activity. As aside results, Lohani and Muthukumarappan (2015) proved that the interaction effects between two independent variables mainly reduce the derived result. For instance, looking at the drying method (DM) and ultrasonication amplitude (UA) effects on apple pomace separately, they reported 6788.3334 and 1876.8693 , respectively; while the interaction (DM*UA) leaded to $1594.1769 \mu \mathrm{mol} \mathrm{TE} / \mathrm{g}$. Thus, herein figures could have been influenced by the interaction effects between the solvents, the extraction modes and the drying temperatures. Seeing the curves' shape propinquity between Figure 4.d and Figure 6.1, we wondered if total phenols content can predict an accurate view on antioxidant activity.

\subsection{Relationship between Total Phenols (Folin-Ciocalteux) Content and Antioxidant Activity $\left(\right.$ ABTS $^{*+}$ )}

On Sorghum products, Awika et al. (2003) announced a very good correlation coefficient between TPC and AOA, with $R^{2}=97.1 \%$. Also, working on guava fruits' extracts in an aqueous methanol, Thaipong et al. (2006) reported $R^{2}=94.09 \%$, which remains a very good correlation coefficient between the two items. Equally important, when Teow et al. (2007) assessed the TPC and AOA of sweet potatoes, they announced $\mathrm{R}^{2}=93.7 \%$. Therefore, taking into account the effect of the interaction between the three factors (temperature, solvent and extraction mode), and looking at the distribution of the spots on the graph, we assessed the potential relationship between the TPC and AOA by using the cubic spline curve (Figure 7). Even though the correlation coefficient $\left(\mathrm{R}^{2}=0.8394\right)$ didn't appear to be as high as those announced by the above authors, but it was still good, since it's higher than 0.7 which was announced acceptable by Candrawinata et al. (2014). Fortunately, as mentioned by Brend, L. Galili, Badani, Hovav and S. Galili (2012), baking or cooking doesn't affect significantly the total phenol content and its derivatives such as total flavonoids and antioxidant activity. Thus, drying in an oven or cooking in a pot may lead to the same nutritional value. As a side remark, we didn't observe any quick browning due to Maillard reaction products (Vijayakumari et al., 2014), within an hour, when B. aethiopum Mart cut pulp was exposed to daily light.

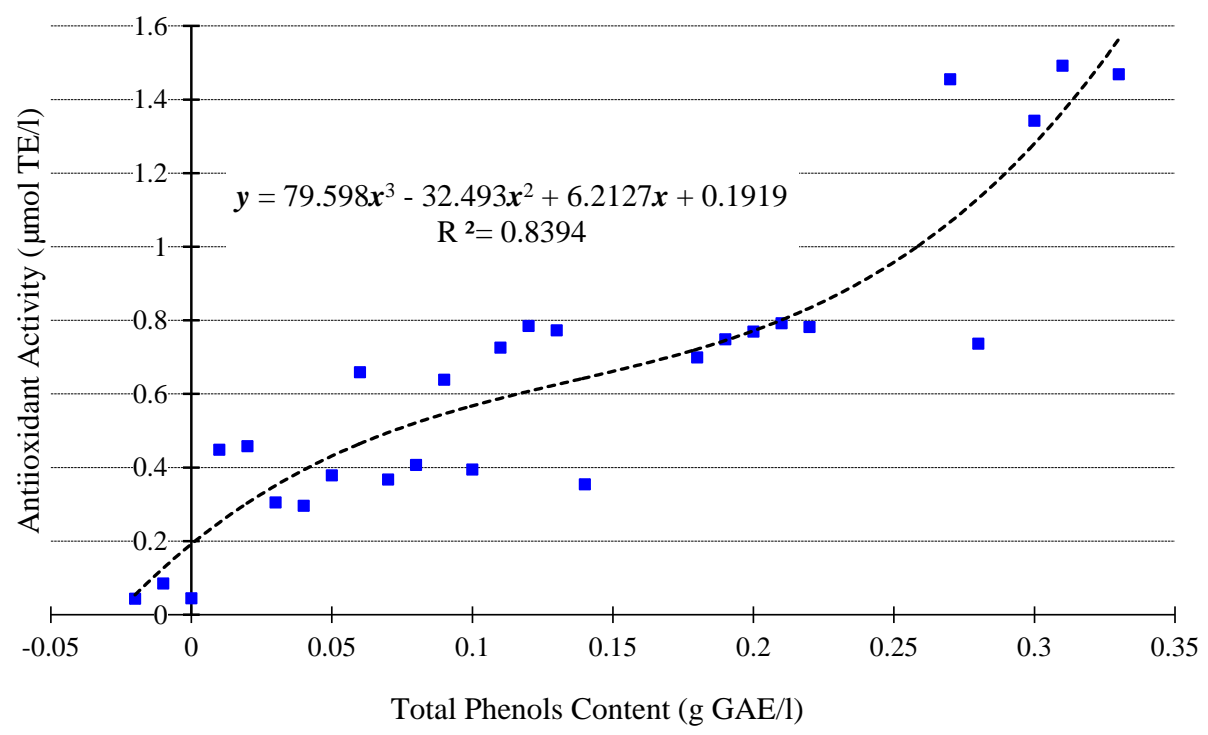

Figure 7. Cubic spline curve giving the relationship between TPC and AOA

Note: Due to duplicates, the number of nodes has been reduced from 108 to 27

\section{Conclusion}

In this investigation, we assessed total phenols content (TPC), total flavonoids content (TFC) and antioxidant activity (AOA) of Borassus aethiopum mature fruits fresh and dried pulps. During TPC, TFC and AOA assessments, six (6) products (Fresh (0), 40,50,60, 70 and $80^{\circ} \mathrm{C}$ ), two (2) extraction modes (decoction and maceration), and three (3) solvents (DW, DW+Aceto, DW+Meth) were used. Truly, extraction and product (fresh or dried) significantly affected TPC, TFC and AOA ( $<<0.0001)$. In contrast the solvent acted partially on the three items. In fact, alone, solvent didn't affect TPC ( $p=0.0778)$, likewise, some interactions with solvent such as extraction*solvent $(\mathrm{p}=0.9197)$ and extraction*solvent*product $(\mathrm{p}=0.0276)$. But, solvent did for TFC and AOA $(\mathrm{p}<0.0001)$. Furthermore, looking at the final product colour, the best drying temperature admitted was $70^{\circ} \mathrm{C}$. 
Consequently, the cheapest solvent and best extractor to estimate TPC was DW, after an extraction by decoction. The extract with DW was 0.1483 (447.866), and it was statistically higher than DW+Aceto and DW+Meth outputs that were 0.1117 (337.334) and $0.1083 \mathrm{~g} \mathrm{GAE} / \mathrm{l}(327.066 \mathrm{mg} \mathrm{GAE} / \mathrm{g}$ ) respectively. Again this experiment proved that low drying temperature allows a better appreciation of TFC. Since flavonoids are denatured by heat, the lowest drying temperature $\left(40^{\circ} \mathrm{C}\right)$ product and extracting with $\mathrm{DW}$ through maceration allowed their best assessment (0.5083 g QE/l; $101.66 \mathrm{mg} \mathrm{QE/g).}$

Furthermore, this experiment consistently proved that red, yellow or yellow-orange fruit pulps have high content of total phenols and exhibit good antioxidant activity. Like Elaeis guineensis ripe fruits' pulp, B. aethiopum Mart mature fruits' pulp is an interesting source of polyphenols, thus it's an important functional food which can provide strong health benefits. Yet important quantities of these big fruits, with more than $30 \%$ fibrous pulp of a whole fruit weight, are still rotting under the trees in the bush. Surprisingly, the ripe fruits are very appreciated of the greater cane rats (Thryonomys swinderianus) and the African giant rats (Cricetomys gambianus), and moreover rural people cook and eat the fibrous pulp. Consequently, for human being, a well-organized collection and a good industrial drying system could give an added value to this wild fruit. Thus, the seasonality effect could be reduced for markets availability. However, in case of industrial drying system in control hot air conditions, the drying temperature is still the most important factor to take care off. Indeed, drying temperature was main effect for TPC. In fact, it greatly affects the total phenols and total flavonoids availability in the cell matrix, thus it affects the antioxidant activity. Additionally, it appeared that the PPO enzyme reaction happened in B. aethiopum Mart pulp drying at $60^{\circ} \mathrm{C}$. Polyphenols content is the base line, and during drying process, the chemical structure of the derived product changes with heat amplitude and its duration.

\section{Acknowledgement}

The authors are extremely grateful to Thapelo Johannes Molatoli; Brakfontein, Mohale's Hoek 800, Lesotho, phone :+266-51643792 and Unisa Conteh Kanu; 7 Karim Drive Lumley, Freetown, Sierra Leone, phone:+232-99764590, for kindly revising the English writing structure of the manuscript.

\section{References}

Albano, C., Negro, C., Tommasi, N., Gerardi, C., Mita, G., Miceli, A., De-Bellis, L., \& Blando, F. (2015). Betalains, Phenols and Antioxidant Capacity in Cactus Pear [Opuntia ficus-indica (L.) Mill.] Fruits from Apulia (South Italy) Genotypes. Antioxidants, 4, 269-280. https://doi.org/10.3390/antiox4020269

Ali, A., Alhadji, D., Tchiegang, C., \& Saïdou C. (2010a). Physico-chemical properties of palmyra palm (Borassus aethiopum Mart) fruits from Northern Cameroon. African Journal of Food Science, 4(3), 115-119.

Ali, A., Fadimatou, B., Tchiegang, C., Saidou, C., \& Adji, M. B. (2010b). Physico-chemical and functional properties of bâtchi or hypocotyle axes of Borassus aethiopum Mart. African Journal of Food Science, 4(10), 635-641.

Ali, A., Tchiegang, C., Alhadji, D., Saidou, C., \& Mohamadou B. A. (2010c). Drying the African Palm Tree (Borassus aethiopum Mart) Fruits in View of Producing Edible Flour. Journal of Food Technology, 8(5), 211-216. https://doi.org/10.3923/jftech.2010.211.216

Antolovich, M., Prenzler, P. D., Patsalides, E., McDonald, S., \& Robards, K. (2002). Methods for testing antioxidant activity. Analyst, 127, 183-198. https://doi.org/10.1039/b009171p

Arunachalam, K., Saravanan, S., \& Parimelazhagan, T. (2011). Nutritional Analysis and Antioxidant Activity of Palmyrah (Borassus flabellifer L.) Seed Embryo for Potential Use as Food Source, Food Science and Biotechnology, 20(1), 143-149. https://doi.org/10.1007/s10068-011-0020-y

Awika, J. M., Rooney, L. W., Wu, X., Prior, R. L., \& Zevallos, L. C. (2003). Screening Methods To Measure Antioxidant Activity of Sorghum (Sorghum bicolor) and Sorghum Products. Journal of Agricultural and Food Chemistry, 51, 6657-6662. https://doi.org/10.1021/jf034790i

Barminas, J. T., Onen, A. I., Williams, E. T., Zaruwa, M. Z., Mamuru, S. A., \& Haggai, D. (2008). Studies on Functional Properties of Borassus Starch From Fresh Germinating Nuts of Giginya (Borassus aethiopum Mart.) Palm. Food Hydrocolloids, 22, 298-304. https://doi.org/10.1016/j.foodhyd.2006.11.018

Brend, Y., Galili, L., Badani, H., Hovav, R., \& Galili, S. (2012). Total Phenolic Content and Antioxidant Activity of Red and Yellow Quinoa (Chenopodium quinoa Willd.) Seeds as Affected by Baking and Cooking Conditions. Food and Nutrition Sciences, 3, 1150-1155. https://doi.org/10.4236/fns.2012.38151

Candrawinata, V. I., Golding, J. B., Roach, P. D., \& Stathopoulos, C. E. (2014). Total phenolic content and 
antioxidant activity of apple pomace aqueous extract: effect of time, temperature and water to pomace ratio. International Food Research Journal, 21(6), 2337-2344.

Dantas, R. L., Silva, S. D. M., Dantas, A. L., Guimarães, G. H. C., Lima, R. P., Nascimento, R. D. S., Da-Silva, M. C. A., Da-Silva, R. S., Santos, D., \& Mendonça, R. M. N. (2016). Bioactive compounds and antioxidant activity of Tacinga inamoena (K. Schum.) [NP Taylor \& Stuppy] fruit during maturation. African Journal of Agricultural Research, 11(17), 1511-1518. https://doi.org/10.5897/AJAR2015.10541

Gil, M. I., Francisco, A., Barberan, T., Pierce, B. H., \& Kader, D. A. (2002). Antioxidant Capacities, Phenolic Compounds, Carotenoids, and Vitamin C Contents of Nectarine, Peach, and Plum Cultivars from California. Journal of Agricultural and Food Chemistry, 50, 4976-4982. https://doi.org/10.1021/jf020136b

Halliwell, B. (1996) Antioxidants in human health and disease. Annual Review Nutrition, 16, 33-50. https://doi.org/10.1146/annurev.nu.16.070196.000341

Jeong, S. M., Kim, S. Y., Kim, D. R., Jo, S. C., Nam, K. C., Ahn, D. U., \& Lee, S. C. (2004). Effect of Heat Treatment on the Antioxidant Activity of Extracts from Citrus Peels. Journal of Agricultural and Food Chemistry, 52, 3389-3393. https://doi.org/10.1021/jf049899k

Karaca, H. C., \& Newman, M. C. (2015). Antimicrobial Efficacy of Natural Phenolic Compounds against Gram Positive Foodborne Pathogens. Journal of Food Research, 4(6), 14-27. http://dx.doi.org/10.5539/jfr.v4n6p14.

Karimi, A., Min, B., Brownmiller, C., \& Lee, S. O. (2015). Effects of Extraction Techniques on Total Phenolic Content and Antioxidant Capacities of Two Oregano Leaves. Journal of Food Research, 4(1), 112-123. http://dx.doi.org/10.5539/jfr.v4n1p112

Khadem, S., \& Marles, R. J. (2010). Monocyclic Phenolic Acids; Hydroxy- and Polyhydroxy-benzoic Acids: Occurrence and Recent Bioactivity Studies. Molecule, 15, 7985-8005. https://doi.org/10.3390/molecules15117985

Lachman, J., Hamouz, K., Sulc, M., Orsák, M., \& Dvorak, P. (2008). Differences in phenolic content and antioxidant activity in yellow and purple-fleshed potatoes grown in the Czech Republic. Plant Soil Environment, 54(1), 1-6.

Lohani, U. C. \& Muthukumarappan, K. (2015). Effect of Drying Methods and Ultrasonication in Improving the Antioxidant Activity and Total Phenolic Content of Apple Pomace Powder. Journal of Food Research, 4(2), 68-77. http://dx.doi.org/10.5539/jfr.v4n2p68

Madrau, M. A., Piscopo, A., Sanguinetti, A. M., Del-Caro, A., Poiana, M., Romeo, F. V., \& Piga, A. (2009). Effect of drying temperature on polyphenolic content and antioxidant activity of apricots. European Food Resources and Technology, 228, 441-448. https://doi.org/10.1007/s00217-008-0951-6

Marinova, D., Ribarova, F., \& Atanassova, M. (2005). Total Phenolics and Total Flavonoids in Bulgarian Fruits and Vegetables. Journal of the University of Chemical Technology and Metallurgy, 40(3), 255-260.

Mkandawire, W., Manani, T. A. N., MKabambe, O., \& Phiri, J. K. (2016). Estimation of Shelf Life of Mango Juice Produced Using Small-Scale Processing Techniques. Journal of Food Research, 5(6), 13-20. http://dx.doi.org/10.5539/jfr.v5n6p13

Moyo, B., Oyedemi, S., Masika, P. J., \& Muchenje, V. (2012). Polyphenolic content and antioxidant properties of Moringa oleifera leaf extracts and enzymatic activity of liver from goats supplemented with Moringa oleifera leaves/sunflower seed cake. Meat Science, 91, 441-447. https://doi.org/10.1016/j.meatsci.2012.02.029

Prior, R. L., Wu, X., \& Schaich, K. (2005) Standardized Methods for the Determination of Antioxidant Capacity and Phenolics in Foods and Dietary Supplements. Journal of Agricultural and Food Chemistry, 53, 4290-4302. https://doi.org/10.1021/jf0502698

Rajha, H. N., El Darra, N., Hobaika, Z., Boussetta, N., Vorobiev, E., Maroun, R. G., \& Louka, N. (2014). Extraction of Total Phenolic Compounds, Flavonoids, Anthocyanins and Tannins from Grape Byproducts by Response Surface Methodology. Influence of Solid-Liquid Ratio, Particle Size, Time, Temperature and Solvent Mixtures on the Optimization Process. Food and Nutrition Sciences, 5, 397-409. https://doi.org/10.4236/fns.2014.54048

Rodríguez, J. C., Gómez, D., Pacetti, D., Núñez, O., Gagliardi, R., Frega, N. G., Ojeda, M. L., Loizzo, M. R., Tundis, R., \& Lucci, P. (2016). Effects of the Fruit Ripening Stage on Antioxidant Capacity, Total Phenolics, 
and Polyphenolic Composition of Crude Palm Oil from Interspecific Hybrid Elaeis oleifera $\times$ Elaeis guineensis. Journal of Agricultural and Food Chemistry, 64, 852-859.

https://doi.org/10.1021/acs.jafc.5b04990

Ruenroengklin, N., Zhong, J., Duan, X., Yang, B., Li, J., \& Jiang, Y. (2008). Effects of Various Temperatures and $\mathrm{pH}$ Values on the Extraction Yield of Phenolics from Litchi Fruit Pericarp Tissue and the Antioxidant Activity of the Extracted Anthocyanins. International Journal of Molecular Science, 9, 1333-1341. https://doi.org/10.3390/ijms9071333

Saleh, E. A., Tawfik, M. S., \& Tarboush, A. H. M. (2011). Phenolic Contents and Antioxidant Activity of Various Date Palm (Phoenix dactylifera L.) Fruits from Saud Arabia. Food and Nutrition Sciences, 2, 1134-1141. https://doi.org/10.4236/fns.2011.210152

Singh, R.S. G., Negib, P. S., \& Radha, C. (2013). Phenolic composition, antioxidant and antimicrobial activities of free and bound phenolic extracts of Moringa oleifera seed flour. Journal of Functional Foods, 5, 1883-1891. https://doi.org/10.1016/j.jff.2013.09.009

Teow, C. C., Truong, V. D., McFeeters, R. F., Thompson, R. L., Pecota, K. V., \& Yencho, G. C. (2007). Antioxidant activities, phenolic and $\beta$-carotene contents of sweet potato genotypes with varying flesh colours. Food Chemistry, 103, 829-838. https://doi.org/10.1016/j.foodchem.2006.09.033

Thaipong, K., Boonprakob, U., Crosby, K., Zevallos, L. C., \& Byrne, D. H. (2006). Comparison of ABTS, DPPH, FRAP, and ORAC assays for estimating antioxidant activity from guava fruit extracts. Journal of Food Composition and Analysis, 19, 669-675. https://doi.org/10.1016/j.jfca.2006.01.003

Veras, A. O. M., Béttega, R., Freire, F. B., Barrozo, M. A. S., \& Freire, J. T. (2012). Drying Kinetics, Structural Characteristics and Vitamins C Retention of Dedo-de-Moca Pepper (Capsicum baccatum) During Convective and Freeze Drying. Brazilian Journal of Chemical Engineering, 29(04), 741-750. https://doi.org/10.1590/S0104-66322012000400006

Vijayakumari, Vengaiah, P.C., \& Kiranmayi, P. (2014). Physicochemical and functional characteristics of powder prepared from palmyra fruit pulp (Borassus flabellifer L.). International Journal of Current Microbiology and Applied Science, 3(9), 352-356.

Wandati, T. W., Kenji, G. M. \& Onguso, J. M. (2013). Phytochemicals in Edible Wild Mushrooms from Selected Areas in Kenya. Journal of Food Research, 2(3), 137-144. http://dx.doi.org/10.5539/jfr.v2n3p137

Wood, J. E., Senthilmohan, S. T., \& Peskin, A. V. (2002). Antioxidant activity of procyanidin containing plant extracts at different pHs. Journal of Food Chemistry, 77, 155-161.

https://doi.org/10.1016/S0308-8146(01)00329-6

\section{Copyrights}

Copyright for this article is retained by the author(s), with first publication rights granted to the journal.

This is an open-access article distributed under the terms and conditions of the Creative Commons Attribution license (http://creativecommons.org/licenses/by/4.0/). 